\title{
Uptake of phosphorus and other nutrients by oats from soils with various clay contents
}

\author{
Arja PaAsikallio \\ Agricultural Research Centre, Isotope Laboratory, 01300 Vantaa
}

\begin{abstract}
The pot experiment was carried out to study the effect of the clay content on the uptake of phosphorus and some other nutrient elements by oats. Two different series of soil mixtures were prepared with increasing additions of clay soil up to $25 \mathrm{vol}$. $\%$ clay, the additions being made both to finesand and Sphagnum peat soils.

The content of phosphorus in plants and the yield increased to some extent in finesand/clay soil mixtures with an increase in the clay content. In peat soil increasing additions of clay soil caused a decrease in the phosphorus content of the plant but had no significant effect on the amount of the yield. In finesand/clay soils the uptake of phosphorus by the oat from the fertilizer increased from 3 to $10 \%$, in peat/clay soils it decreased from 60 to $20 \%$ with an increasing clay content of the soils.

The isotope dilution method was not applicable in the determining of the labile phosphorus of the experimental soil mixtures. This was assumed to be due to the small concentrations and concentration differences in soluble native soil phosphorus and to the strong fixing capacities of the soils. The contents of other nutrient elements in plants generally decreased with an increasing clay content. The most marked exceptions in this respect were the content of phosphorus in plants growing on finesand/clay soils and the content of potassium and manganese on peat/clay soils.
\end{abstract}

The quantity of the clay fraction is usually found to be inversely proportional to the quantity of plant available phosphorus in the soil. In some cases, however, the clay content of the soil has not affected the solubility of phosphorus applied to soil or the effect has been slight (LARSEN et al. 1965, HALSTEAD 1967) and the increase in the clay content has even been reported to have increased the amount of plant available phosphorus (Olsen and Watanabe 1963, Baldovinos and Thomas 1967).

The purpose of this study was to investigate the effect of clay additions to finesand and peat soils on the uptake of phosphorus and other nutrients by plants. Simultaneously the isotope dilution method for the determination of labile phosphorus (L-values) in these soil mixtures was tested.

\section{Material and methods}

Pot experiments with oats were conducted in three successive years. The model soils used were prepared by mixing various portions of clay with both 
finesand and peat. All these soils were of virgin origin. The experiment was repeated using the same soil mixtures in order to check the isotope dilution method. When finesand/clay soils were used for the first time the plants were grown under artificial light, all the other experiments were made outdoors.

Preparation of the experimental soils

Heavy clay soil of the illitic type (clay content 84 wt. \%) was mixed with finesand, the final clay $(<2 \mu)$ percentages (in volume basis) of the soil mixtures being $0.6,9.1,13.1,17.3,21.5$ and 25.7. In Sphagnum peat/heavy clay soils the clay percentages were $0,4.2,8.4,12.6$., 16.8, 21.0 and 25.2. The soils were fertilized with $200 \mathrm{mg} \mathrm{N}$ as $\mathrm{NH}_{4} \mathrm{NO}_{3}, 200 \mathrm{mg} \mathrm{K}$ as $\mathrm{KCl}, 300 \mathrm{mg} \mathrm{Mg}$ as $\mathrm{MgSO}_{4} \cdot 7 \mathrm{H}_{2} \mathrm{O}$ and $2 \mathrm{~g} \mathrm{Ca}$ as $\mathrm{CaCO}_{3}$ per one litre of soil. Radiophosphorus was added combined with the fertilizer phosphorus. The treatment in the first year was $75 \mathrm{mg} \mathrm{P}$ and in the second year $100 \mathrm{mg} \mathrm{P}$ per litre of soil as $\mathrm{NaH}_{2} \mathrm{PO}_{4}$. $2 \mathrm{H}_{2} \mathrm{O}$. The specific activity of the solution was about $0.5 \mathrm{mCi} \mathrm{P} 32 / \mathrm{g} \mathrm{P}$. Trace element applications were: $\mathrm{Fe}$ and $\mathrm{Mn} 20 \mathrm{mg}, \mathrm{Cu}$ and $\mathrm{Zn} 5 \mathrm{mg}, \mathrm{B}$ and Mo 1 $\mathrm{mg}$ per one litre of soil. When repeating the experiment the soils were fertilized as above.

After the mixing of the fertilizers and the addition of water up to $60 \%$ of the water holding capacity of the soils, they were allowed to equilibrate for a week, when repeating the experiment for two weeks. Then 31 seeds of oat (var. Pendek) were sown per pot containing 6 litres of soil. Four replicates were used. The pots were watered with deionized water, the excess water was collected and reused for watering. The plants were cut after a five weeks growing period. In the second year the oats were heading while in the first year they were at a more premature stage at the cutting time.

\section{Plant analyses}

The plant material was dried at $105^{\circ} \mathrm{C}$ and ashed at $450^{\circ} \mathrm{C}$ overnight. The ash was dissolved in $0.2 \mathrm{~N} \mathrm{HCl}$ and $\mathrm{Ca}, \mathrm{Mg}$ and $\mathrm{K}$ were determined by atomic absorption spectrophotometry. Phosphorus was determined colorimetrically by the vanado-molybdate method and the trace elements spectrographically. The radioactivity was counted with an end window GM counter in $50 \mathrm{mg}$ of the plant ash on the planchet, simultaneously one millilitre of the P 32 fertilizer solution with $50 \mathrm{mg}$ of inactive ash was evaporated in the planchet and counted. The specific activities (cpm P 32/g P) of the plant material and the P 32 - fertilizer phosphorus solution were also determined in quinolinephosphomolybdate precipitate by the modified method of MACKENZIE and DEAN (1948). The $\mathrm{L}-$ values for the labile soil phosphorus were calculated according

to the equation: $\mathrm{L}=\left(\frac{\mathrm{S}_{\mathrm{f}}}{\mathrm{S}_{\mathrm{p}}}-1\right) \mathrm{X}$, where $\mathrm{S}_{\mathrm{f}}$ and $\mathrm{S}_{\mathrm{p}}$ designate the specific activities of fertilizer and plant, respectively. $\mathrm{X}$ is the amount of fertilizer phosphorus supplied per unit volume of soil (LARSEN 1952). 
The soils were extracted with an acid ( $\mathrm{pH} 4.65)$ ammonium acetate (VuoRINEN and MäKITIE 1955) for one hour in volumetric ratio 1:5. The cations of the soil extracts were determined by atomic absorption spectrophotometry, the phosphorus colorimetrically by the molybdenum blue method. The soil $\mathrm{pH}$ was determined from the soil-water suspension $(1: 2.5)$. The adsorption of phosphorus was determined by shaking the soils for 18 hours in $\mathrm{NaH}_{2} \mathrm{PO}_{4} \cdot 2 \mathrm{H}_{2} \mathrm{O}$ - water solution in the volumetric ratio $1: 5$ containing 20 and $100 \mathrm{ppm} \mathrm{P}$ in peat/clay and in finesand/clay soils, respectively. The $20 \mathrm{ppm} \mathrm{P}$ solution was too diluted for finesand/clay soils, the adsorption of phosphorus from this solution was nearly complete. The specific activities of the solutions were about $0.7 \mathrm{mCi} \mathrm{P} 32$ (as sodiumorthophosphate) $/ \mathrm{g} \mathrm{P}$ and the solution was 0.01 $\mathrm{N}$ with respect to $\mathrm{CaCl}_{2}$. After shaking the soil-water suspension was centrifuged and filtered. One $\mathrm{ml}$ of each, the filtrate and the standard solution, were evaporated in the planchet and the radioactivity was counted. The percentage of adsorption in the soil was calculated from the difference in activities of the standard and filtrate solutions. The residual soil was washed, dried and extracted as before. The activity of one $\mathrm{ml}$ of the extract was counted. The percentage of the extraction was calculated from the adsorbed activity. The adsorption and extraction procedure of manganese was carried out in a similar manner. Carrier-free Mn 54 solution containing about $10 \mathrm{nCi}$ Mn $54 / \mathrm{ml}$ was used.

The effect of the clay content on the mineral content of the plant was tested by variance analysis.

Table 1. Characteristics of the experimental soils.

\begin{tabular}{|c|c|c|c|c|c|c|c|c|c|}
\hline \multirow{2}{*}{$\begin{array}{c}\text { Clay } \\
\text { vol. \% }\end{array}$} & \multirow{2}{*}{$\begin{array}{c}\text { Bulk } \\
\text { density } \\
\mathrm{g} / \mathrm{cm}^{3}\end{array}$} & \multirow{2}{*}{$\mathrm{pH}$} & \multicolumn{7}{|c|}{ Acid ammonium acetate extractable elements, $\mathrm{mg} /$ litre of soil } \\
\hline & & & $\mathrm{Ca}$ & $\mathrm{Mg}$ & K & $\mathbf{P}$ & Mn & $\mathrm{Fe}$ & $\mathrm{Al}$ \\
\hline \multicolumn{10}{|c|}{ Finesand/heavy clay } \\
\hline 0.6 & 1.47 & 5.44 & 8 & 5 & 18 & 0.10 & 0.5 & 14.4 & 199 \\
\hline 9.1 & 1.43 & 5.92 & 215 & 225 & 56 & 0.10 & 3.4 & 12.3 & 154 \\
\hline 13.1 & 1.42 & 5.94 & 330 & 288 & 73 & 0.10 & 4.9 & 11.3 & 153 \\
\hline 17.3 & 1.40 & $6 \cdot 01$ & 445 & 398 & 84 & 0.20 & 5.9 & 10.0 & 154 \\
\hline 21.5 & 1.38 & 6.00 & 950 & 498 & 115 & 0.25 & 7.2 & 10.9 & 153 \\
\hline 25.7 & 1.36 & 6.11 & 971 & 568 & 157 & 0.20 & 8.2 & 11.0 & 152 \\
\hline \multicolumn{10}{|c|}{ Sph. peat/heavy ciay } \\
\hline 0 & 0.08 & 3.98 & 120 & 49 & 21 & 2.25 & 2.5 & 0.9 & 2.5 \\
\hline 4.2 & 0.13 & 4.48 & 430 & 120 & 49 & 1.43 & 6.3 & 2.9 & 7.0 \\
\hline 8.4 & 0.18 & 4.65 & 650 & 320 & 70 & 1.23 & 7.0 & 3.0 & 9.5 \\
\hline 12.6 & 0.23 & 4.70 & 1150 & 528 & 105 & 1.03 & 11.3 & 3.2 & 8.5 \\
\hline 16.8 & 0.28 & 4.90 & 1225 & 618 & 120 & 0.93 & 13.5 & 3.7 & 10.5 \\
\hline 21.1 & 0.34 & 4.85 & 1275 & 705 & 133 & 0.75 & 14.0 & 3.7 & 24.0 \\
\hline 25.3 & 0.39 & 5.00 & 1526 & 840 & 160 & 0.70 & 16.5 & 4.9 & 27.0 \\
\hline
\end{tabular}




\section{Results}

Characteristics of the experimental soils

Table 1 shows some characteristics of the experimental soils before the fertilization. The liming levelled the differences in the $\mathrm{pH}$-values of the soils to some extent. The $\mathrm{pH}$-values, determined after harvest, with an increasing clay content, were the following: in finesand/clay soils $7.2,7.3,7.4,7.5,7.7$

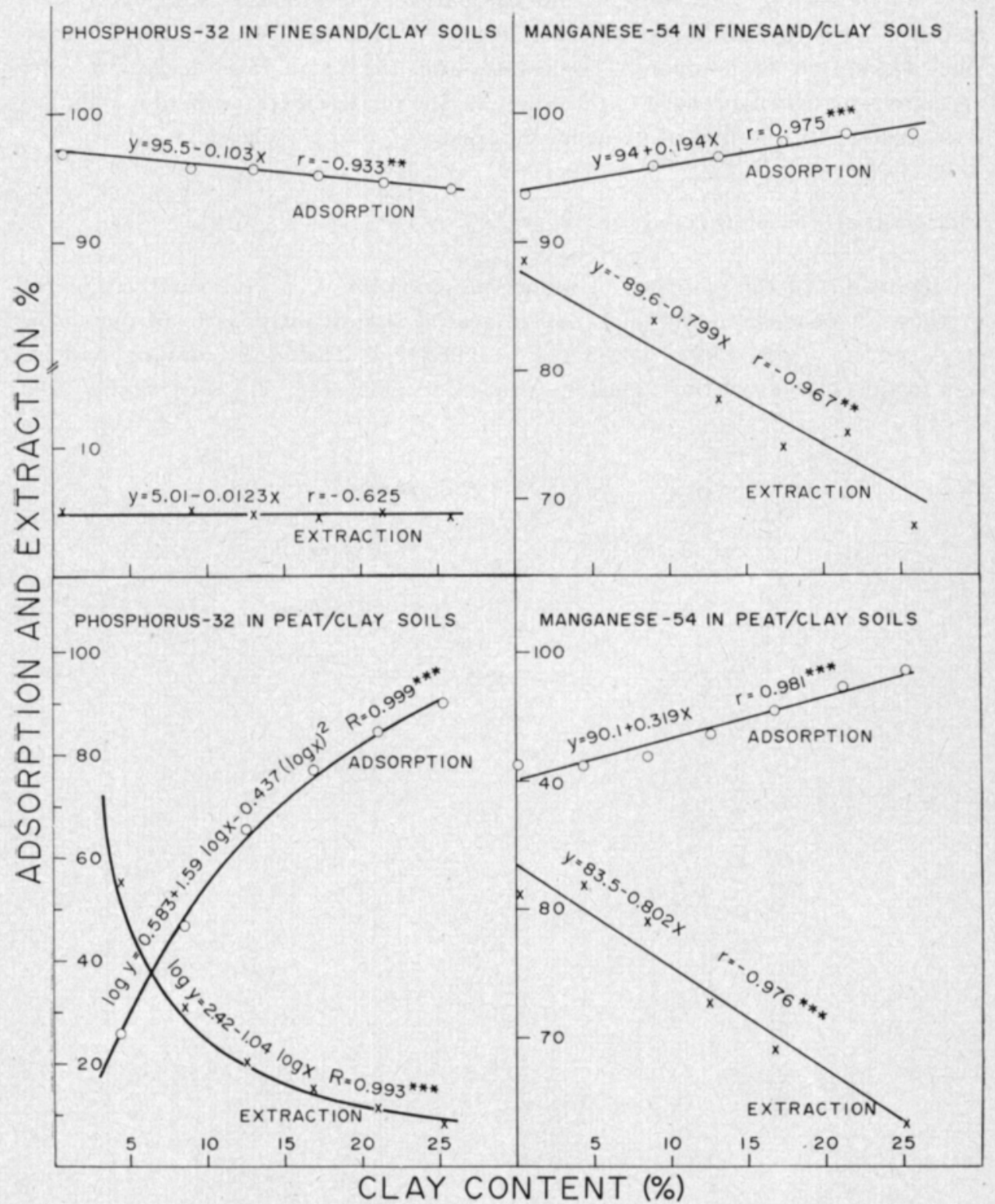

Fig. 1. Relations between the adsorption and extraction of phosphorus and manganese (y) and soil clay content $(\mathrm{x}), \mathrm{r}=$ correlation coefficients at $99.9^{* * *}, 99^{* *}$ and $95^{*}$ per cent levels. 
and 7.8 and in peat/clay soils $6.8,7.2,7.4,7.5,7.5$ and 7.5. In the former soils the greatest difference between the $\mathrm{pH}$-values was thus 0.6 and in the latter $0.7 \mathrm{pH}$-unit. The specific conductivity determined after harvest varied in finesand/clay soils from 11.3 to 3.0 and in peat/clay soils from 6.3 to $9.510 \mathrm{x}$ mho with an increasing clay content.

Fig. 1 shows the adsorption and extraction of phosphorus and manganese of unfertilized soils. In finesand/clay soils phosphorus showed a strong adsorption but the extraction was slight and changes in the clay content did not affect it. In peat/clay soils the adsorption of phosphorus increased considerably with an increasing clay content and the extractable amounts were large with respect to the finesand/clay soils and decreased with an increasing clay content. The adsorption of manganese increased and the extraction decreased with an increasing clay content in both soil series, the relative extraction of manganese was much stronger than of phosphorus irrespective of the clay content.

The contents of phosphorus in plants

The yields of the plants growing on finesand/clay soils were small compared to those in peat/clay soils and they increased significantly with an increasing clay content $\left(y=4.93+0.233 x ; r=0.968^{* *}\right)$. The clay content had no significant effect on the yields in peat/clay soils (Fig. 2). The figures also

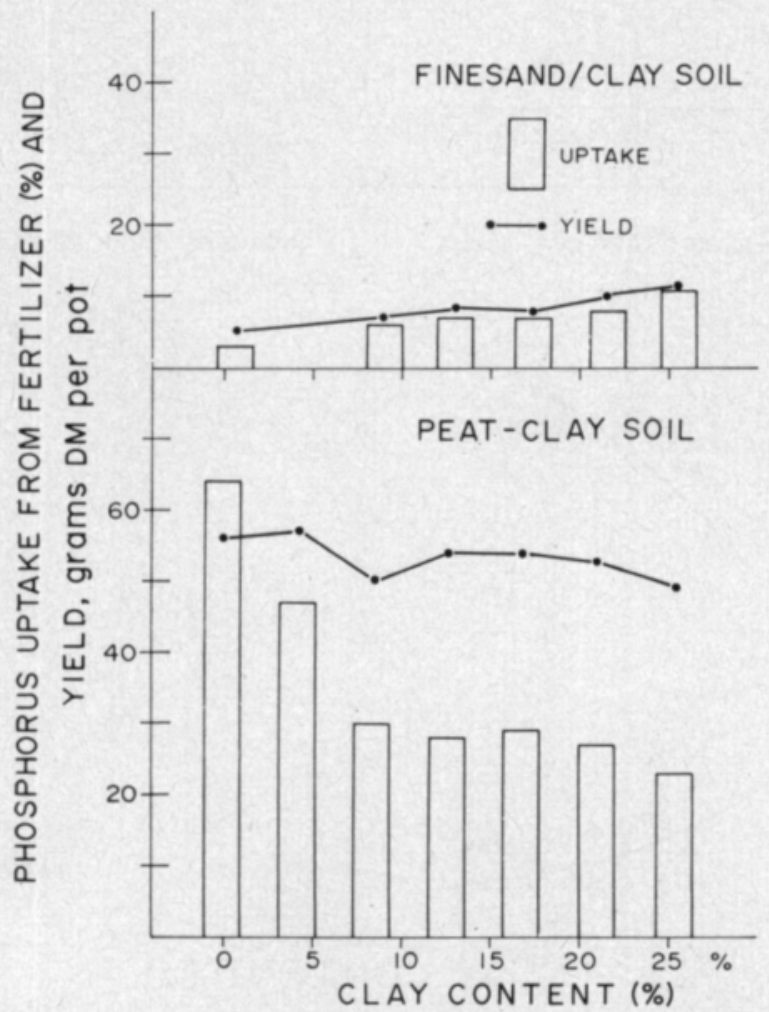

Fig. 2. The uptake of phosphorus by plants from fertilizer and the yield plotted against the increasing clay content in finesand and peat soils. 


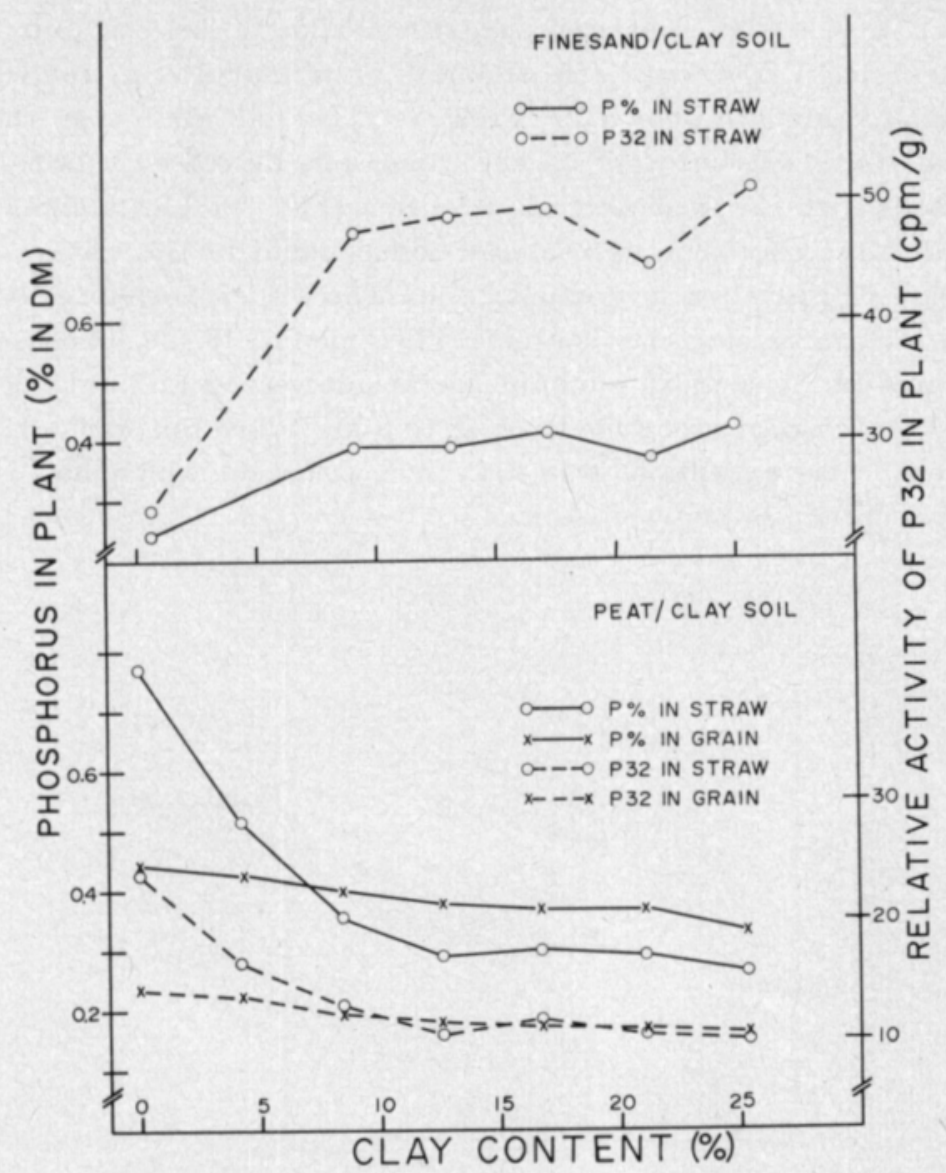

Fig. 3. The phosphorus and radiophosphorus contents of plants as a function of increasing clay content in finesand and peat soils.

show the total amount of phosphorus taken up by the plants expressed in percentages from the added fertilizer phosphorus. The phosphorus content of the plants in the first treatment (no clay addition) of the finesand/clay soil series was significantly smaller than the content of other treatments between which there were no significant differences (Fig. 3). In peat/clay soils the phosphorus content in plants decreased with an increasing clay contents (Fig. 3), the two first additions of clay having the heaviest decreasing effects on the $\mathrm{P}$ content of straw. In grain the decrease was less marked. The contents of radiophosphorus in plants are also shown in the same figures.

In both soil series the specific activity of the plants increased with the clay content in the first year (Fig. 4). The changes in the specific activity of the plants were expressed in per cents so that the control treatment of each soil series was marked as $100 \%$. On the basis of the specific activity of the plants and the amount of fertilizer phosphorus added to unit volume of soil, the native labile soil phosphorus was calculated as $37,18,15,20,20$ and 18 $\mathrm{mg} \mathrm{P} / 1$ of soil with an increasing clay content. The calculations for the phosphor- 
us contents in peat/clay soils gave negative values except in pure peat soil which gave $7 \mathrm{mg} \mathrm{P} / 1$ of soil. The amounts of phosphorus extracted by acid ammonium acetate are shown in Table 1 . The following year the specific activities of the plants growing on the same soils decreased especially in the peat/clay soils with the increasing clay content (Fig. 4). The labile phosphorus values in finesand/clay soils were almost independent of the clay content and on an average larger than in peat/clay soils where the phosphorus content increased with an increasing clay content. The amounts of phosphorus extracted after the harvest by acid ammonium acetate decreased in finesand/clay soils from 5 to 3 and in peat/clay soils from 18 to $8 \mathrm{mg} \mathrm{P} / 1$ of soil with an increasing clay content. An exception was the pure peat soil which had the lowest phosphorus content in this soil series.

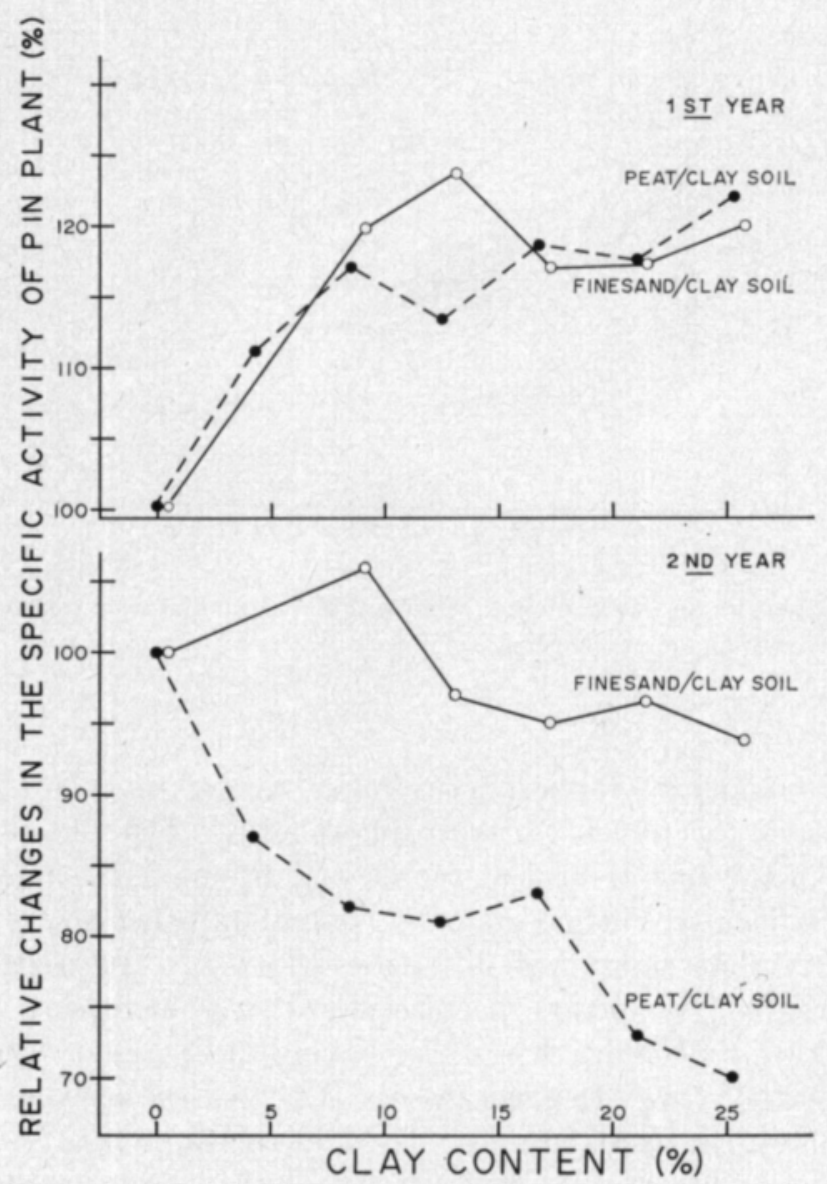

Fig. 4. Relative changes in the specific activity of phosphorus in plants growing on finesand and peat soils with increasing clay content. The relative value of $100 \%$ given to soils without clay addition. 
The contents of calcium, magnesium, potassium and some trace elements in plants

The calcium and magnesium contents in plants decreased in both soils with an increasing clay contant (Fig. 5 and Table 2). Clay addition had no clear effect on the potassium content in grain (peat/clay soils) or on its content in straw (finesand/clay soils) while the potassium content in straw on peat soils increased markedly with an increasing clay content. This increase was more than two-fold and was highly significant.

The trace elements determined were iron, manganese, copper and molybdenum. Zinc and nickel were determined only in the grain. In the finesand/clay soils the manganese, copper and molybdenum contents in plants decreased significantly with an increasing clay content. The changes in the amounts of clay did not have any effect on the iron content of plants (Fig. 6 a). The trace element concentrations of plants also in peat/clay soils generally decreased significantly with an increasing clay content except molybdenum which did not show any differences (Fig. 6 b). The changes in the manganese content in the straw were exceptional, also in the grain there was a similar but more

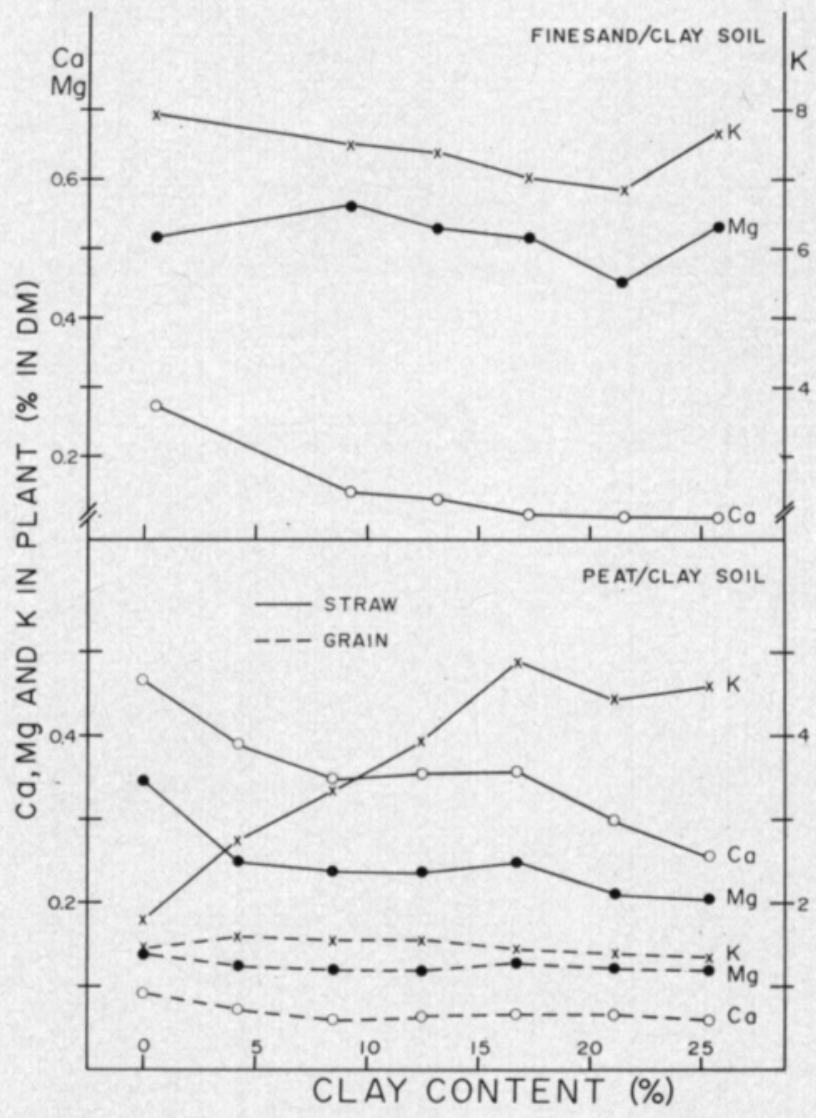

Fig. 5. The content of $\mathrm{Ca}, \mathrm{Mg}$ and $\mathrm{K}$ in plant as a function of increasing clay content in finesand and peat soils. 


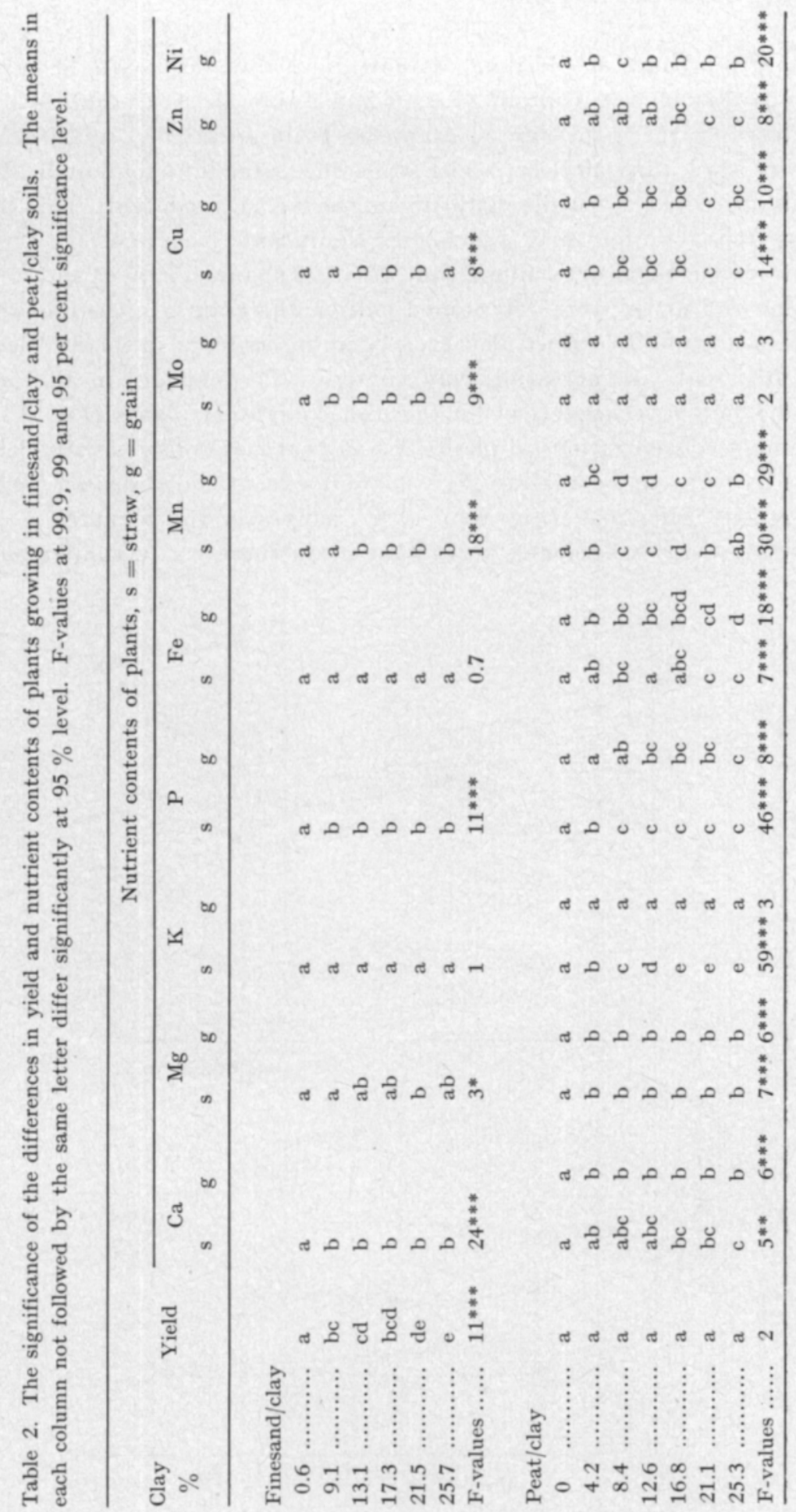




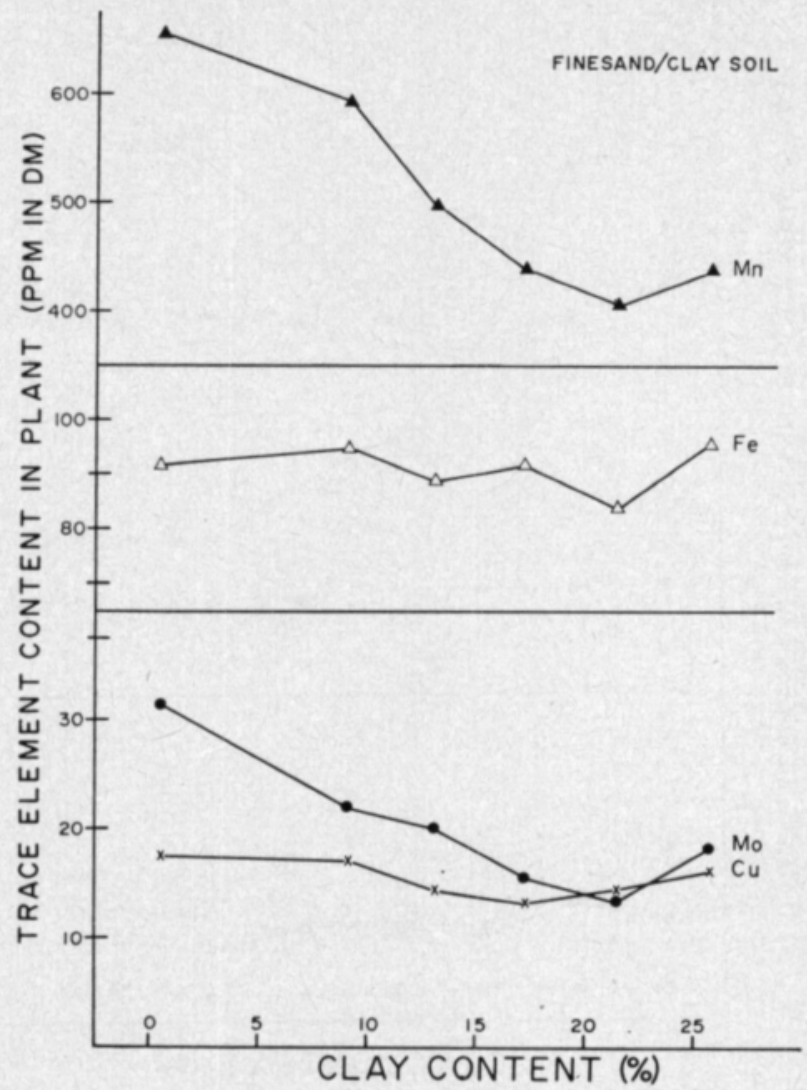

Fig. 6 a. The contents of some trace elements in plant (sraw of oats) as a function of increasing clay content in finesand soil.

gently sloping $\mathrm{V}$-formed curve. The iron content of the plants showed also a temporary minimum at the same point as in manganese. The copper content of the plants decreased with an increasing clay content, the grain having a higher copper content than the straw. The nickel in grain increased with increasing clay per cent. Table 2 shows the significances of the differences in yield and mineral contents of plants.

\section{Discussion}

With increasing silt and clay contents the amount of soluble cations in the soil generally increases and the soluble phosphate diminishes (SILLANP $\ddot{A}$ $1962 \mathrm{a}, \mathrm{b}$, LAKANEN and HyväRINEN 1971). There are changes also in the bulk density, $\mathrm{pH}$, permeability, cation exchange and buffer capacity of the soil. When an equal fertilization was given to such a series of soil mixtures with a varying clay content, it levelled some of the differences, such as those in the hydrogen ion concentration and the nutritional status of the soil. The less native nutrients there were in the soil, the more available were the nutri- 


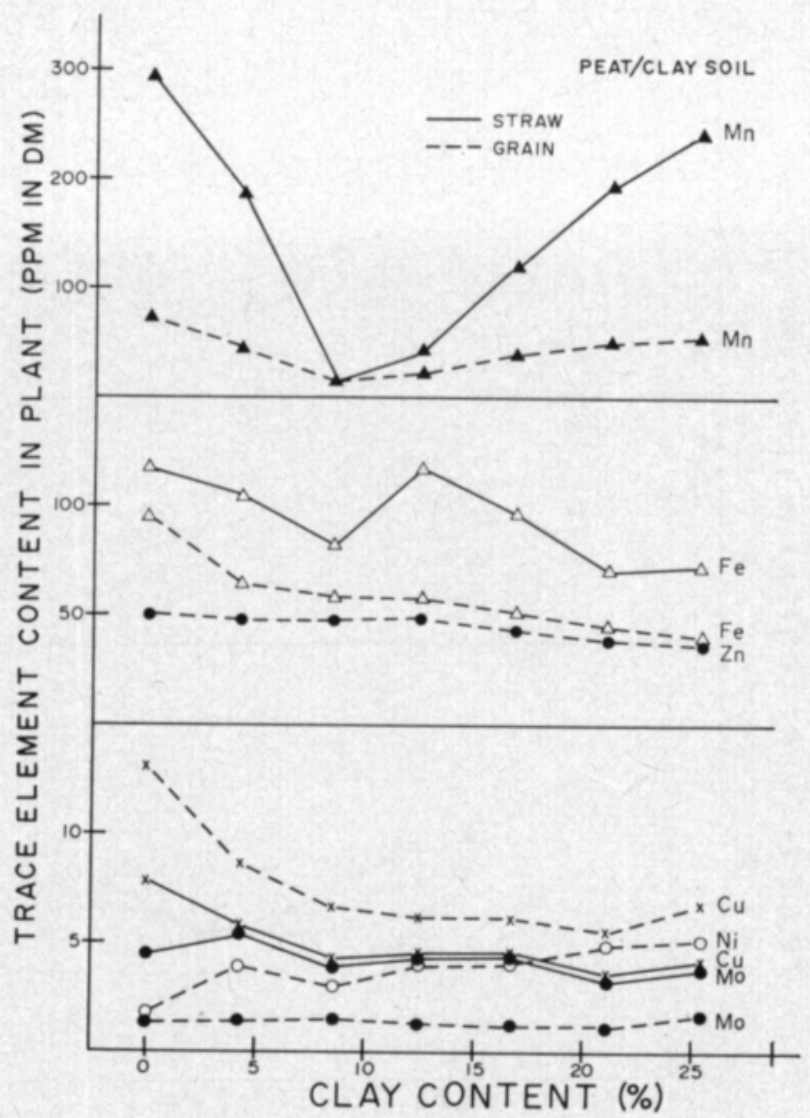

Fig. 6 b. The contents of some trace elements in plant (straw and grains of oats) as a function of increasing clay content in peat soil.

ents given in fertilizers. The plant uptake of phosphorus, potassium and manganese, however, made an exception, the last two only in peat/clay soils. The adsorption capacity of soils generally increased with an increasing clay content while the extraction percentage decreased.

In some cases the sanding of clay soils has been found to improve the moisture conditions of the soil, however, mixing of the ssand soil" into the clay soil may turn the soil to a "mortarn, as happened in this experiment to the finesand/clay mixtures. Evidently the degree of the coarseness of the ssand soil h has a bearing on this phenomenon (LAINE 1969). The high content of aluminum and iron in finesand was evidently responsible for the high fixing capacity of phosphorus by the soil mixtures leading to a decrease in the availability of phosphorus to plants. Aluminum and iron may cause precipitation of soluble phosphorus as insoluble compounds under acid conditions. At high $\mathrm{pH}$-values also Ca may affect the solubility of phosphorus (HEMwaLL 1957, SillanpäÄ 1961, Lakanen and Vuorinen 1963, Juo and Ellis 1968). Clay additions increased the uptake of phosphorus by plants and especially the yield. The simultaneous decrease in the specific conductivity of the soil might also have had an effect. 
The clay fraction in the soil has often been found to be responsible for the fixing of phosphorus. However, the content of active iron and aluminum may not only be a function of the clay content but may depend on the parent material and on soil formation processes. For example SALONEN (1941) found that gyttja clay, the soil B horizon and Carex peat soils had the highest phosphorus fixing capacities, while heavy clay, sandy clay, sand soils and the soil A horizon had lower fixing capacities. OLSEN and WATANABE (1963) reported that the uptake of $\mathrm{P}$ by plants in calcareous soils increased with an increasing clay content. BALdovinos and ThомAs (1967) had similar results with acid soils.

Clay soil, especially heavy clay, has been found to be a good amendment for peat soils. In this experiment the clay soil added to peat soil did not affect significantly the yield, but lowered the contents of most nutrients in plants. Since all the soils were well-fertilized, even the increase in the soluble potassium, caused by claying the soils, was not able to increase the yield. In field experiments where claying had led to a yield increase, the increase in soluble potassium besides the rise in soil $\mathrm{pH}$, has been suggested as being an important although not the only factor affecting the yield response (PEssi 1960).

The amounts of soil soluble $\mathrm{Al}$ and $\mathrm{Fe}$, the initial level of available $\mathrm{P}$ and the adsorption and the extraction percentages of $\mathrm{P}$ were important in determining the amount of plant response to applied phosphorus in this experiment.

The isotope dilution method did not prove satisfactory for determining the soil labile phosphorus. This was supposed to be due to the lack of sensitivity of the method for determining such low concentrations and small concentration differences as the soils initially contained, and also due to the high phosphorus fixing capacity of the clay and finesand soils. For soils of high fixing capacity the values of soluble $\mathrm{P}$ are likely to be overestimated (Mekhael et al. 1965, McConaghy et al. 1966, Amer et al. 1969). This was apparently the case with the finesand/clay soils. The method is based on the assumption that equilibrium has been reached between the soil solution and soil solid. This was apparently not the case in this study. Amer (1962) supposed that some negative values reported in the literature (THOMPSON et al. 1961) may be accounted for by the low sensibility of the carrier method. In this study negative labile phosphorus values were obtained for the peat/clay mixtures. The higher the specific activity of the plant, the less soluble native phosphorus ought to exist in the soil solution to dilute the added radiophosphorus-fertilizer solution according to the principle of isotope dilution. The increase in plant specific activity with an increasing clay content should then indicate the simultaneous decrease in the soil native labile phosphorus (Fig. 4). When the values of labile soil phosphorus were determined for the second year, they ought to have indicated the soil residual phosphorus after harvest. The changes in the specific activity showed (Fig. 4) that the less clay there was in the peat soil the poorer the soil became with respect to $\mathrm{P}$. In finesand/clay soils the changes in the specific activity were slighter. In peat/clay soils the uptake of potassium by plants increased with an increasing clay content, while the uptake of calcium and magnesium, and also potassium, in finesand/clay soils decreased. The dissolution of the unexchangeable potassium 
in a clay fraction has been found to be effective in the clayed peat soils (KERÄNEN 1946).

The results of NAIR and CotTEniE (1971) showed that amorphous $\mathrm{Fe}_{2} \mathrm{O}_{3}$, possibly by way of surface coating of finer sized particles (clay and silt) may retain a large proportion of $\mathrm{Zn}, \mathrm{Al}, \mathrm{Cu}, \mathrm{Mn}$ and $\mathrm{Fe}$. The amount of soluble manganese and to some extent iron depends also on the soil $\mathrm{pH}$ and the redox potential. With a decreasing soil $\mathrm{pH}$ the amount of soluble manganese increases and in soils with an equal $\mathrm{pH}$ the amount of soluble manganese is the larger the lower the redox potential. A high content of clay, compactness and a high water content of the soil will lower the redox potential (SCHEFFER and SchACHTSCHABEL 1973). The decrease in the manganese content of the plant might at least partly have been due to the rise in the soil $\mathrm{pH}$ from 6.8 to 7.4 , that is to the $8.4 \%$ of clay, hereafter the $\mathrm{pH}$ no longer increased but the probable decrease in the redox potential made the manganese more available.

Clay addition to the peat soil decreased significantly the copper and zinc content of plants. Copper is known to be fixed strongly by clay minerals and zinc behaves to some extent like copper. Copper is also fixed strongly by organic matter, the fixing is, however, more due to the origin than the amount of organic matter (GUPTA and MACKAY 1966) and in peat soils to the degree of decomposition of the peat.

In finesand/clay soils the uptake of molybdate by plants decreased with an increasing clay content while in peat/clay soils the clay addition did not seem to affect the uptake. Copious amounts of soluble $\mathrm{P}$ in peat soils with a small clay content might have had a preventive influence on the uptake of Mo (Bingham and Garber 1960, Bingham 1963) overshadowing the possible effect of clay on fixing Mo.

The increase in the nickel content of plants with an increasing clay content apparently was caused by the natively higher content of nickel in clay soil compared to peat soil.

\section{REFERENCES}

Amer, F. 1962. Determination of $\mathrm{P}^{32}$ exchangeable phosphorus in soils. Radioisotopes in soil-plant nutrition studies. Proc. IAEA/FAO Symp. Bombay. p. 43-58. Vienna.

- - Mahdi, S. \& Alradi, A. 1959. Limitations in isotopic measurements of labile phosphate in soils. J. Soil Sci. 20: $91-100$.

Baldovinos, F. \& Thомas, G. W. 1967. The effect of soil clay content on phosphorus uptake. Soil Sci. Soc. Amer. Proc. 31: $680-682$.

Brngham, F. T. 1963. Relation between phosphorus and micronutrients in plants. Soil Sci. Soc. Amer. Proc. 27: 389-391.

- - \& GARber, M. J. 1960. Solubility and availability of micronutrients in relation to phosphorus fertilization. Soil Sci. Soc. Amer. Proc. 24: 209-213.

GuptA, U. C. \& MAc KAY, D. C. 1966. The relationship of soil properties to exchangeable and water-soluble copper and molybdenum status in podzol soils of Eastern Canada. Soil Sci. Soc. Amer. Proc. 30: 373-375.

HalsteAd, R. L. 1967. Chemical availability of native and applied phosphorus in soils and their textural fractions. Soil Sci. Soc. Amer. Proc. 31: 414-419. 
Hemwall, J. B. 1957. The role of soil clay minerals in P fixation. Soil Sci. 83: 101-108.

Juo, A. S. R. \& Ellis, B. G. 1968. Chemical and physical properties of iron and aluminum phosphates and their relation to phosphorus availability. Soil Sci. Soc. Amer. Proc. 32: $216-221$.

Keränen, T. 1946. Kaliumista Suomen maalajeissa. Summary: On potassium in Finnish soils. Acta Agr. Fenn. 63: 1-114.

LAINE, T. 1969. Hiesusaven hiekoituskoe 1959-68. Koetoim. ja Käyt. 26: 40.

LAKANEN, E. 1967. The effect of liming on the adsorption and exchange characteristics of trace elements in soils. Acta Agr. Scand. 17: 131-139.

- - \& HyVÄRINEN, S. 1971. The effect of some soil characteristics on the extractability of macronutrients. Ann. Agr. Fenn. 10:135-143.

- $-\&$ Vuorinen, J. 1963. The effect of liming on the solubility of nutrients in various Finnish soils. Ann. Agr. Fenn. 2: 91-102.

LARSEN, S. 1952. The use of P 32 in studies on the uptake of phosphorus by plants. Plant and Soil 4: 1-10.

- - Gunary, D. \& Sutron, C. D. 1956. The rate of immobilization of applied phosphate in relation to soil properties. J. Soil Sci. 16: 141-148.

McConaghy, S., Stewart, J. W. B. \& Malek, M. 1966. Soil phosphate status as measured by isotopic-exchange and other techniques. Int. Soc. Soil Sci., Aberdeen, Trans. Comm. II and IV. Soil chemistry and fertility. p. 151-160.

Mackenzie, A. J. \& Dean, L. A. 1948. Procedure for measurement of P 31 and P 32 in plant material. Anal. Chem. 20: 559-560.

Mekhael, D., Amer, F. \& Kadry, L. 1965. Comparison of isotope dilution methods for estimation of plant available soil phosphorus. Isotopes and radiation in soil-plant nutrition studies. Proc. IAEA/FAO Symp. Ankara. p. 437-448. Vienna.

NAIR, K. P. P. \& CotTEnIE, A. 1971. A statistical evaluation of the interrelationships between particle-size fractions, free iron oxide, and trace elements. J. Soil Sci. 22: 203-209.

Olsen, S. R. \& Watanabe, F. S. 1963. Diffusion of phosphorus as related to soil texture and plant uptake. Soil Sci. Soc. Amer. Proc. 27: 648-653.

PEssi, Y. 1960. On the significance of mineral soil as a soil improving agent on fens on the basis of prolonged field tests at Leteensuo experimental station. Acta Agr. Fenn. 95, 3: $16-27$.

SALONEN, M. 1941. Fosforin esiintymismuodoista Suomen maalajeissa. Summary: Uber die Formen des Vorkommens von Phosphor in den Bodenarten Finnlands. Acta Agr. Fenn. 48: 1-124.

Scheffer, F. \& Schachtschabel, P. 1973. Lehrbuch der Bodenkunde. 448 p. 8th Ed. Stuttgart.

SillanpäÄ, M. 1961. The effect of liming on the solubility of phosphorus in a muddy clay soil. Acta Agr. Scand. 11: $360-368$.

- -1962 a. On the effect of some soil factors on the solubility of trace elements. Agrogeol. Publ. 81: 1-24.

- $-1962 \mathrm{~b}$. Trace elements in Finnish soils as related to soil texture and organic matter content. J. Scient. Agric. Soc. Finl. 34: 34-40.

Thompson, E. J., Oliveira, A. L. F., Moser, U. S. \& Black, C. A. 1961. Evaluation of laboratory indexes of absorption of soil phosphorus by plants: II. Plant and Soil 13: 28-38 .

Vuorinen, J. \& Mäkitie, O. 1955. The method of soil testing in use in Finland. Agrogeol. Publ. 63: 1-144. 


\title{
Saven lisäyksen vaikutus kauran kivennäisainepitoisuuksiin hieta- ja turvemailla
}

\author{
Arja Paasikallio \\ Maatalouden tutkimuskeskus, Isotooppilaboratorio, 01300 Vantaa
}

Saviaineksen ravinteita pidättävää ominaisuutta tutkittiin astiakokeena sekoittamalla aitosavea nousevin pitoisuuksin (suurin lisäys oli 30 til. \% aitosavea) kahteen niukkaravinteiseen, fysikaalisilta ominaisuuksiltaan toisistaan huomattavasti poikkeavaan maahan eli karkeaan hietaan ja maatumattomaan rahkaturpeeseen. Koekasvina oli kaura. Ennen koetta maat lannoitettiin yhtäläisesti.

Hieta/savi maissa kasvaneiden kasvien sato jäi pieneksi turve/savi maiden satoon verrattuna. Sadon määrä kasvoi kuitenkin merkitsevästi savipitoisuuden lisääntyessä. Turve/savi maissa ei ollut merkitseviä eroja satomäärien välillä.

Hieta/savi maissa kauran fosforin otto lisätystä lannoitteesta kasvoi 3:sta 10:een prosenttiin, turve/savi maissa se pieneni 60:stä 20:een prosenttiin kasvavan savipitoisuuden mukana (Kuva 2).

Fosforin lisäksi määritettiin kauran kalsium` kalium-, magnesium-, rauta-, mangaani-, kupari- ja molybdeenipitoisuudet (Kuvat 5 ja 6). Kasvien kivennäisainepitoisuudet yleensä pienenivät savipitoisuuden kasvaessa, poikkeuksena olivat kuitenkin kasvien fosforipitoisuus (Kuva 3), joka kasvoi savipitoisuuden mukana hieta/savi maissa, kaliumpitoisuus, joka nousi jyrkästi turve/savi maissa sekä mangaanipitoisuus, joka turve/savi maissa aluksi laski mutta kasvoi korkeimpia savipitoisuuksia kohti.

Isotooppilaimennusmenetelmää kokeiltiin maitten liukoisen fosforin määrittämiseksi. Radiofosfori lisättiin lannoitefosforiliuoksen kanssa maahan ja kasvien radioaktiivisuus mitattiin noin 5 viikon kuluttua kylvöstä. Kasvien ominaisaktiivisuuksien (Kuva 4), lannoiteliuoksen ominaisaktiivisuuden ja mahan lisätyn lannoitefosforimäärän perusteella voidaan laskea maan labiilin fosforin måärä. Menetelmän kåyttö ei kuitenkaan soveltunut k.o. maaseoksille, minkä seikan arveltiin johtuvan mm. maitten luontaisen liukoisen fosforin pienestä pitoisuudesta ja pitoisuuseroista sekä maitten voimakkaasta fosforinsitomiskyvystä, joka määritettiin radiofosforin avulla. Vertailun vuoksi määritettiin myös mangaanin sitoutuminen maihin radioaktiivisen mangaanin avulla (Kuva 1). 